\title{
Obituary
}

\author{
Editor: Henry R. Rollin
}

Karl Leonhard, Emeritus Professor, Nervenklinik Charite, Berlin, East Germany (Corresponding Fellow).

Karl Leonhard died unexpectedly on 23 April 1988, shortly after his 84th birthday.

Only in the past few years has his work gained international recognition. His concepts have their base in the tradition of Wernicke and Kleist, but extend far beyond. The ever-increasing interest in his work, especially outside Germany, can be demonstrated by the fact that his books and journal articles have been translated into many languages and his books are repeatedly published.

He was born on 21 March 1904 in Edelsfeld in Bavaria as the son of a Lutheran priest. He attended the 'Humanistic Gymnasium' in Weiden, Upper Palatinate until 1923, before studying medicine in Erlangen, Berlin and Munich. After working as a medical assistant for a short period at the Mental Hospital of the University of Erlangen, he accepted a position at the Hospital Gabersee in Upper Bavaria in 1931. A year later he was promoted to the position of Assistant Medical Director. Kleist offered Leonhard a position as Assistant Medical Director at the Mental Hospital of Frankfurt's University in 1936, and he was granted the title Professor in 1944. In 1955, he was made full Professor of Psychiatry and Neurology at the Medical Academy in Erfurt before transferring to the Mental Hospital of the Humboldt University in Berlin in 1957.

After his retirement he devoted himself fully to psychiatric research for which he was generously provided with facilities and personnel.

It is beyond the scope of this obituary to discuss in detail the life work of this remarkable man. Without question, among his most important contributions must be mentioned: the description of cycloid psychosis, the characterisation of the defective conditions of schizophrenia, which he referred to as "systematical schizophrenias" and the differentiation of bipolar and monopolar forms of affective illnesses. He laid strong emphasis on the phenomenological cross-section and on the longitudinal section. Genetic relationships and the ordinal position of the patient among his siblings were also points of emphasis in his work.

Professor Leonhard's contributions to the study of neuroses and psychotherapy have been given too little recognition, taking into consideration that he can justly be referred to as the founder of behavioural therapy, although he himself never wanted recognition for this fact.

His very original ideas regarding human sexuality were presented in his book Instincts and Primitive Instincts of Human Sexuality, which was published in 1964. He thereby used aspects of the phylogenesis of human sexuality to demonstrate apparent relationships. In Human Expression, through Mimic, Gesture and Phonics, which was printed in 1976, he demonstrated once again his ability to recognise and categorise systematically human expressive behaviour.

He achieved success too in neurological research. His analysis of numerical types, his definition of the 'Frontal-lobe Syndrome' as well as his definition of ideokinetic motor aphasia have not been contradicted.

How could such an excellent body of scientific research pass almost unnoticed? Could it have been the result of the individuality of his scientific orientation, which was not only contrary to trends in contemporary scientific thought, but rejected common beliefs outside? Or could it have been the lack of emphasis on a control element in his methodology, which he did not consider as essential? A third possible reason could lie in Leonhard's personality, which he himself referred to as introverted and compulsive.

Frederick Kräupl Taylor, Emeritus Physician, The Bethlem Royal and Maudsley Hospitals, London

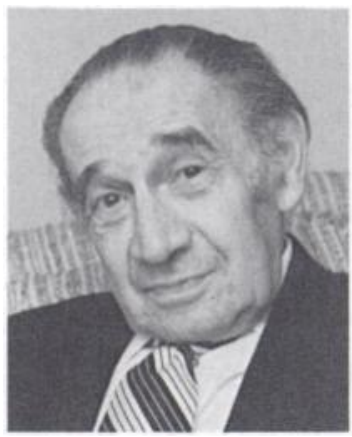

Dr Frederick Kräupl Taylor died in London on 24 March 1989, aged 83. He provided the factual basis for his own obituary in a "Perspective", (Bulletin of the Royal College of Psychiatrists, January 1982 , $6,2-4)$. The bulk of the piece is devoted to a summarised account of his principal contributions: three books (The Analysis of Therapeutic Groups; Psychopathology: its Causes and Symptoms; The Concepts of Illness, Disease and Morbus), several key papers, and the development of his own individual brand of 'prokalectic' psychotherapy. This account is introduced by a brief description of how, in 
1939, he was forced by the Nazis to abandon his original intention to specialise in internal medicine in his native Czechoslovakia. After a few weeks in a concentration camp he came to England as a refugee. At first not permitted to practise medicine, he worked for two years in the pathological laboratory at The Retreat; here he first came to meet psychiatric patients and, in his spare time, developed an interest in mathematics, statistics, philosophy and psychology. From 1941 onwards he trained as a psychiatrist at the Crichton Royal and Netherne and had a brief encounter with psychoanalysis before an invitation from Sir Aubrey Lewis brought him to the Maudsley Hospital, where he was a consultant from 1948 until his formal retirement in 1971. Subsequently he continued to work productively for the remainder of his life.

But in themselves, the bare facts do not account for Kräupl Taylor's special position in post-war British psychiatry. He belonged to no school and remained a somewhat isolated figure, whose warm personality and quizzical humour were seen to best advantage in a close working relationship. Many members of a whole generation of Maudsley trainees, several now occupying senior positions, have testified to the direct influence of ' $K-T$ ' on their development and outlook. What impressed them was the unusual combination of professional dedication, sound clinical judgement, erudition, and an abiding interest in the application of scientific thinking to clinical issues which never overshadowed therapeutic concern. At the Rodney Club, the social club for out-patients that he founded and supervised, he demonstrated how long-term support could help chronically sick and disabled patients.
Over and above his personal qualities, however, Kräupl Taylor provided a rare example of the psychotherapist who was constantly prepared to examine rigorously the implications of his own activities and was intellectually equipped to do so. His relatively late discovery of Karl Jaspers' General Psychopathology influenced his thinking greatly and he became progressively more sceptical about the psychoanalytical enterprise. The two chapters, entitled 'The Development of Freud's Psychopathological Theories' which terminate the first edition of his Psychopathology were, significantly, omitted from the second edition, and his searching, scholarly chapter on 'Dynamic Aspects of Psychiatry' in Volume 5 of the Handbook of Psychiatry identifies the positive placebo effect in what he called 'remedial bonding' as the core feature of all psychotherapeutics.

His original mind and compassionate integrity will be greatly missed by his colleagues and his many friends.

MS

\section{RICHARD STUART SCOTT WILKIE, formerly Consultant Psychiatrist, Medical Director, St Brendan's Hospital, Bermuda}

The death of Dr Wilkie was listed in the Bulletin (December 1988). He was tragically killed on 30 September 1988.

As a tribute to his work in Bermuda his friends and colleagues are endeavouring to raise money to establish a Richard Wilkie Memorial Fund for the purpose of bringing a speaker on some aspect of forensic psychiatry to Bermuda each year. It is also proposed that the new Forensic Unit will be named after him. 